\title{
Bacterial production and respiration in subtropical Hong Kong waters: influence of the Pearl River discharge and sewage effluent
}

\author{
Xiangcheng Yuan ${ }^{1,2}$, Kedong Yin ${ }^{2,3, *}$, Paul J. Harrison ${ }^{1}$, Wei-Jun Cai ${ }^{4}$, Lei He ${ }^{2}$, \\ $\mathrm{Jie} \mathrm{Xu}^{1}$
}

${ }^{1}$ Atmospheric, Marine and Coastal Environment (AMCE) Program, Hong Kong University of Science and Technology, Clear Water Bay, Kowloon, Hong Kong SAR

${ }^{2}$ Key Laboratory of Tropical Marine Environmental Dynamics, South China Sea Institute of Oceanology, Chinese Academy of Sciences, Guangzhou, PR China

${ }^{3}$ Australian Rivers Institute, Griffith University (Nathan Campus), Brisbane, Queensland 4111, Australia

${ }^{4}$ Department of Marine Sciences, University of Georgia, Athens, Georgia 30602, USA

\begin{abstract}
Hong Kong waters are influenced by the Pearl River discharge in the west, coastal/ oceanic waters in the east, and year-round domestic sewage effluent in the Victoria Harbour area. Seven cruises were conducted at 12 stations across the Hong Kong water in the dry and wet seasons to examine how the Pearl River outflow and sewage effluent discharge influenced the distributions of dissolved oxygen (DO), dissolved inorganic carbon (DIC), bacterial production (BP) and bacterial respiration (BR). Surface DO saturation was usually $\sim 80 \%$, and surface partial pressure of carbon dioxide $\left(\mathrm{pCO}_{2}\right)$ averaged $\sim 570 \mu \mathrm{atm}$ at all 12 stations. The undersaturated DO and supersaturated $\mathrm{pCO}_{2}$ indicated that Hong Kong waters were heterotrophic and a net source of $\mathrm{CO}_{2}$ to the atmosphere, except during periods of phytoplankton blooms when $\mathrm{pCO}_{2}$ became very low $(<200 \mu a t m)$. The Pearl River discharge in the wet season decreased $\mathrm{DO}$ and increased $\mathrm{pCO}_{2}$ and $\mathrm{BP}$ in the estuarine-influenced waters in comparison with the coastal/oceanic waters. Sewage effluent exerted a strong influence on carbon dynamics and $\mathrm{CO}_{2}$ efflux as surface $\mathrm{pCO}_{2}$ was significantly correlated with $\mathrm{NH}_{4}$, an indicator of sewage effluent. BR in Hong Kong waters was $\sim 100$ to $400 \mathrm{mmol} \mathrm{C} \mathrm{m}{ }^{-2} \mathrm{~d}^{-1}$ in July and November 2005. The BR fraction accounted for 50 to $80 \%$ of total dark community respiration (DCR) in coastal/oceanic waters with less eutrophic inputs, but increased to $>90 \%$ of DCR in more eutrophic waters near the sewage discharge site, likely due to the decrease in phytoplankton biomass. Contribution of BR to the $\mathrm{CO}_{2}$ efflux was $\sim 3$ to $10 \mathrm{mmol} \mathrm{C} \mathrm{m} \mathrm{C}^{-1}$, which was $\sim 50 \%$ (varied from 16 to $130 \%$ ) of the total $\mathrm{CO}_{2}$ efflux. This study has important implications for severely anthropogenically impacted coastal areas, as they may be an important source of atmospheric $\mathrm{CO}_{2}$ due to active BR.
\end{abstract}

KEY WORDS: Bacterial production $\cdot$ Bacterial respiration $\cdot \mathrm{CO}_{2} \cdot$ Sewage effluent $\cdot$ Pearl River estuary

\section{INTRODUCTION}

Coastal and estuarine waters receive large amounts of inorganic nutrients as well as terrestrial organic matter from river and sewage effluent discharge. Eutrophication has become a major concern in these areas (NRC 2000), since eutrophication not only increases primary production (Lohrenz et al. 1999), but also increases high bacterial production (BP) and bac- terial respiration (BR) (Del Giorgio et al. 1997, Choi et al. 2005) and consequently hypoxic events such as those observed in the Yangtze River plume (Li et al. 2002), the Gulf of Mexico (Rabalais et al. 1994), and the Loire estuary (Abril et al. 2003). In addition, high BR also results in a net $\mathrm{CO}_{2}$ source (or $\mathrm{CO}_{2}$ supersaturation), especially when there are high terrestrial inputs of organic matter in marine ecosystems (Smith \& Hollibaugh 1993, Del Giorgio et al. 1997), as suggested by 
studies in the East China Sea (Chen et al. 2003), Mississippi River plume (Chin-Leo \& Benner 1992), northern North Sea during a coccolithophore bloom (Robinson et al. 2002b) and eutrophic lakes (Biddanda et al. 2001). However, it is generally unclear whether terrestrial and sewage inputs lead coastal waters to be more heterotrophic or autotrophic.

Recently, $\mathrm{CO}_{2}$ supersaturation has been reported in a number of estuarine systems such as the York, Satilla, Scheldt and Pearl River estuaries (Raymond et al. 1997, Cai \& Wang 1998, Frankignoulle et al. 1998, Dai et al. 2006). $\mathrm{CO}_{2}$ super- or undersaturation provides qualitative evidence of net hetero- or autotrophy (Raymond \& Bauer 2000). However, whether the global coastal oceans are net heterotrophic or autotrophic depends on the area and variations in many seasonal factors (Ducklow \& McCallister 2004). Many studies of $\mathrm{CO}_{2}$ variations focused on temperate coastal waters, in which $\mathrm{CO}_{2}$ concentrations are variable (from $75 \%$ undersaturation to $200 \%$ oversaturation), whereas the subtropical region has been less well studied (Ducklow \& McCallister 2004, Cai et al. 2006). One recent study reported that coastal waters of the South China Sea (SCS) were dominated by oversaturated $\mathrm{CO}_{2}(\sim 400$ to $\sim 600 \mu \mathrm{atm})$ in July 2000, May 2001 and November 2002 (Zhai et al. 2005), but further studies are necessary with more monthly coverage. Hong Kong is situated on the northern side of the SCS, and hence our study of seasonal $\mathrm{CO}_{2}$ variations provides further evidence of the heterotrophy or autotrophy in coastal waters of the subtropical SCS, and quantify the contribution of heterotrophic bacteria to the process.

As the population in southern China (including Hong Kong) continues to increase, the inorganic nutrient loading is also increasing through domestic and industrial sewage discharge in the Pearl River estuary (PRE) and adjacent waters. Apart from the increases in inorganic nutrients, the river discharge and sewage effluent may export organic matter into coastal waters, which could be oxidized by bacteria (Kirchman et al. 1991) and lead to an increase in partial pressure of carbon dioxide $\left(\mathrm{pCO}_{2}\right)$. The input of organic matter into coastal ecosystems alters biogeochemical cycling processes (e.g. nutrient and carbon cycling) in coastal waters. Previous studies in these areas suggest that these anthropogenic inputs of inorganic nutrients and organic matter have led to variations in phytoplankton biomass, oxygen and $\mathrm{CO}_{2}$ in the PRE and adjacent waters (Yin et al. 2004, Cai et al. 2004, Dai et al. 2006). However, there is still little information about how these inputs from the PRE and sewage effluent affect heterotrophic bacteria and influence their rates of oxygen consumption and $\mathrm{CO}_{2}$ release.
In 2005 and 2006 we conducted 7 cruises and visited 12 stations during each cruise to (1) assess whether the influence of the PRE and sewage effluent discharge resulted in net heterotrophy in Hong Kong waters; (2) investigate the variations in dissolved oxygen (DO), $\mathrm{CO}_{2}$, and $\mathrm{BP}$ during dry and wet seasons; and (3) determine the contribution of bacterial respiration to oxygen consumption and $\mathrm{CO}_{2}$ release in these coastal waters. This is a study on severely anthropogenically impacted subtropical coastal areas, which are an important source of atmospheric $\mathrm{CO}_{2}$ due to $\mathrm{BR}$.

\section{MATERIALS AND METHODS}

Study area. Hong Kong is situated on the eastern side of the PRE (Fig. 1). The annual average Pearl River discharge is $10500 \mathrm{~m}^{3} \mathrm{~s}^{-1}$, with $20 \%$ occurring during the dry season from October to March and $80 \%$ during the wet season from April to September (estimated by Yin et al. 2000 from Zhao 1990). The PRE carries pollutants and high nutrient loadings due to local sewage and agricultural inputs (Cai et al. 2004, Yin et al. 2004). Hong Kong waters receive $>2000000 \mathrm{t}$ of sewage effluent daily from the local sewage discharge in Victoria Harbor (VH). In 2001 the Hong Kong government implemented the Harbor Area Treatment Scheme (HATS), which collects and treats $70 \%$ of the sewage that was previously discharged into $\mathrm{VH}$.

Sampling. Sampling was conducted at 12 stations (Fig. 1) and 2 depths: (1) 1 to $4 \mathrm{~m}$ below the surface; and (2) $2 \mathrm{~m}$ above the bottom during 7 cruises in June, July and November 2005 and March and April, July and November 2006. Stns 1 to 12 correspond to the same stations used in the Hong Kong Environmental Protection Department's monitoring program (EPD, www.epd.gov.hk) (Table 1). Stns 1 and 2 represent the western waters. Stns 3, 4 and 5 are near the sewage discharge site in $\mathrm{VH}$, and Stn 8 is considered to be a reference station, since it receives little anthropogenic input from the PRE or the local sewage discharge site. Stns 9 to 12 in the southern waters represent a eutrophic gradient from Stn $9(\sim 10 \mathrm{~m})$ to Stn $12(\sim 35 \mathrm{~m})$ in deeper coastal waters. The vertical profiles of salinity, temperature and chlorophyll a ( $\mathrm{chl}$ a) were measured with a YSI ${ }^{\circledR} 6600$ sensor.

Chl a, BA and BP. Chl a fluorescence was measured with a YSI ${ }^{\circledR} 6600$ sensor, and chl a was also measured on discrete water samples using the in vitro fluorometric method with acetone extraction and measured on a Turner Designs TD-700 fluorometer (Knap et al. 1994).

Bacterial abundance (BA) was determined using the 4',6-diamidino-2-phenylindole (DAPI) direct count method (Porter \& Feig 1980). Samples $(2 \mathrm{ml})$ were collected in microcentrifuge tubes (Axygen), fixed with 


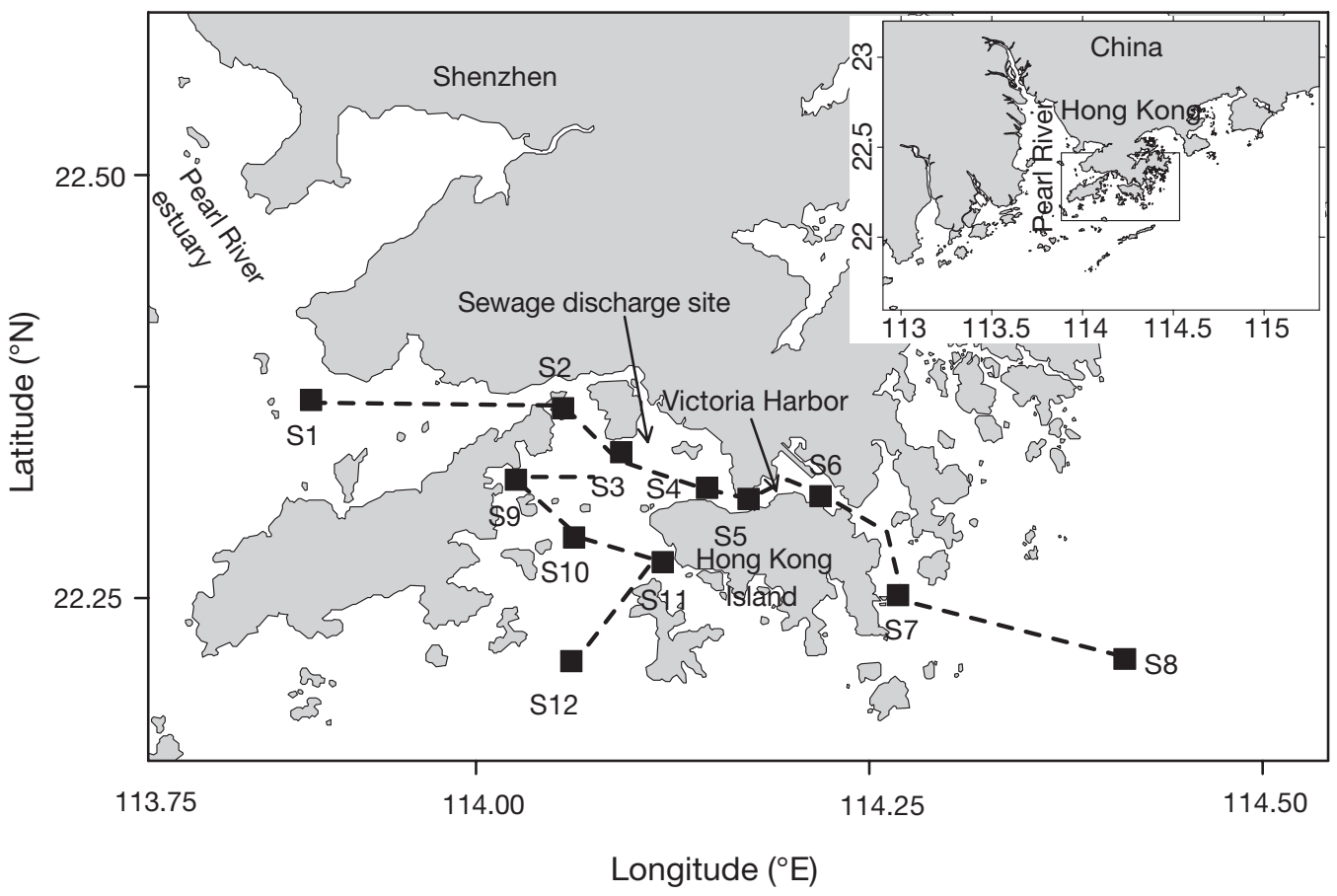

Fig. 1. Sampling stations along 2 transects (- - - -): a west to east transect from Stn 1 in estuarine waters to Stn 8 in eastern waters (EW), and a north to south transect from Stns 3 to 12. The new sewage discharge site is located between Stns 3 and 4

$2 \%$ (final concentration) formaldehyde and filtered onto a $0.22 \mu \mathrm{m}$ polycarbonate membrane filter (Poretics). Bacterial cells were observed with an epifluorescence microscope (Olympus BX41) with blue excitation $(485 \mathrm{~nm})$ and recorded on digital images. Stained bacterial cells on the digital images were acquired and counted with Image Pro ${ }^{\circledR}$ Plus software (Media Cybernetics).
BP was determined as described by Simon \& Azam (1989). ${ }^{3} \mathrm{H}$-leucine (final concentration $30 \mathrm{nM}$, specific activity $55.9 \mathrm{Ci} \mathrm{mmol}^{-1}$ ) was added to $2 \mathrm{ml}$ subsamples (triplicate) with one control fixed by $5 \%$ trichloroacetic acid (TCA). The subsamples were incubated for leucine incorporation for $1 \mathrm{~h}$, and the linearity of the incorporation of leucine was tested in a separate time series experiment (data not shown). The incubation

Table 1. Monthly average depths, temperature, salinity, dissolved oxygen (DO) and DO \% saturation (DOs) (mean \pm 1 SD) at the surface in the wet and dry seasons during 2005 and 2006. Station numbers used by Environmental Protection Department (EPD) Hong Kong are also given

\begin{tabular}{|c|c|c|c|c|c|c|c|c|c|c|}
\hline \multirow[b]{2}{*}{ Stn } & \multirow[b]{2}{*}{ EPD } & \multirow[b]{2}{*}{$\begin{array}{l}\text { Depth } \\
\text { (m) }\end{array}$} & \multicolumn{4}{|c|}{ Wet season } & \multirow{2}{*}{$\begin{array}{c}\text { Temp. } \\
\left({ }^{\circ} \mathrm{C}\right)\end{array}$} & \multicolumn{2}{|c|}{ _ Dry season- } & \multirow[b]{2}{*}{$\begin{array}{l}\text { DOs } \\
(\%)\end{array}$} \\
\hline & & & $\begin{array}{l}\text { Temp. } \\
\left({ }^{\circ} \mathrm{C}\right)\end{array}$ & Salinity & $\begin{array}{c}\mathrm{DO} \\
(\mu \mathrm{M})\end{array}$ & $\begin{array}{l}\text { DOs } \\
(\%)\end{array}$ & & Salinity & $\begin{array}{c}\mathrm{DO} \\
(\mu \mathrm{M})\end{array}$ & \\
\hline 1 & NM2 & 12 & $28 \pm 0.7$ & $14 \pm 7$ & $194 \pm 25$ & $87 \pm 13$ & $24 \pm 3$ & $31 \pm 1$ & $209 \pm 13$ & $97 \pm 4$ \\
\hline 2 & WM4 & 32 & $27 \pm 1$ & $24 \pm 4$ & $178 \pm 3$ & $81 \pm 2$ & $23 \pm 3$ & $33 \pm 0.6$ & $203 \pm 13$ & $93 \pm 3$ \\
\hline 3 & WM3 & 19 & $26 \pm 0.5$ & $25 \pm 4$ & $169 \pm 6$ & $76 \pm 3$ & $23 \pm 3$ & $33 \pm 0.3$ & $206 \pm 31$ & $94 \pm 9$ \\
\hline 4 & VM7 & 11 & $26 \pm 1$ & $27 \pm 4$ & $169 \pm 16$ & $78 \pm 7$ & $23 \pm 3$ & $33 \pm 0.3$ & $184 \pm 25$ & $86 \pm 5$ \\
\hline 5 & VM5 & 13 & $26 \pm 0.8$ & $27 \pm 4$ & $181 \pm 6$ & $82 \pm 3$ & $23 \pm 3$ & $33 \pm 0.3$ & $163 \pm 34$ & $77 \pm 9$ \\
\hline 6 & VM2 & 14 & $26 \pm 1.1$ & $29 \pm 3$ & $209 \pm 34$ & $96 \pm 16$ & $23 \pm 3$ & $33 \pm 0.3$ & $181 \pm 31$ & $80 \pm 10$ \\
\hline 7 & EM3 & 25 & $25 \pm 0.6$ & $31 \pm 1$ & $225 \pm 34$ & $104 \pm 18$ & $23 \pm 3$ & $34 \pm 0.3$ & $219 \pm 19$ & $99 \pm 6$ \\
\hline 8 & MM8 & 31 & $26 \pm 0.3$ & $30 \pm 2$ & $253 \pm 50$ & $117 \pm 23$ & $25 \pm 3$ & $34 \pm 0.3$ & $225 \pm 16$ & $105 \pm 10$ \\
\hline 9 & SM10 & 6 & $28 \pm 1$ & $23 \pm 5$ & $272 \pm 31$ & $126 \pm 14$ & $23 \pm 3$ & $33 \pm 1$ & $222 \pm 19$ & $103 \pm 10$ \\
\hline 10 & SM9 & 9 & $27 \pm 1$ & $23 \pm 6$ & $172 \pm 3$ & $78 \pm 2$ & $23 \pm 3$ & $33 \pm 1$ & $206 \pm 22$ & $95 \pm 5$ \\
\hline 11 & WM1 & 33 & $28 \pm 1$ & $24 \pm 5$ & $191 \pm 13$ & $89 \pm 6$ & $23 \pm 3$ & $33 \pm 0.5$ & $206 \pm 19$ & $94 \pm 3$ \\
\hline 12 & SM6 & 15 & $28 \pm 1$ & $22 \pm 6$ & $250 \pm 56$ & $113 \pm 26$ & $23 \pm 3$ & $33 \pm 0.5$ & $216 \pm 16$ & $100 \pm 2$ \\
\hline
\end{tabular}


was terminated by adding TCA ( $5 \%$ final concentration). After centrifugation and aspiration of the supernatant, pellets were rinsed and centrifuged twice with $1 \mathrm{ml}$ of $5 \% \mathrm{TCA}$, and then scintillation cocktail was added to the vial. The incorporated ${ }^{3} \mathrm{H}$ was determined using a Perkinelmer Wallac, 1414 scintillation counter. Two experiments were conducted to determine the in situ conversion factors ( $\mathrm{CFs}$ ), and the estimated CFs were $\sim 6 \pm 4$ and $\sim 4.6 \pm 2 \mathrm{~kg} \mathrm{C}$ mol leucine ${ }^{-1}$ in the wet and dry season, respectively, assuming a cellular biomass of bacteria $\left(20 \mathrm{fg} \mathrm{C} \mathrm{cell}^{-1}\right.$ ). Bacterial growth efficiency (BGE) was also calculated using an empirical $\mathrm{CF}$ of $\sim 3 \mathrm{~kg} \mathrm{C}$ mol leucine ${ }^{-1}$ (Pedrós-Alió et al. 1999).

DO, DCR and BR. DO was determined in duplicate by Winkler titration, as outlined in the Joint Global Ocean Flux Study (JGOFS) protocols (Knap et al. 1994). DO solubility was calculated according to Benson \& Krause (1984). After 4 to $5 \mathrm{ml}$ of water was allowed to overflow from the $60 \mathrm{ml}$ custom made BOD bottles when taking DO samples from the Niskin bottle, Winkler reagents were added. Winkler titrations were carried out in the laboratory with an automated titration apparatus (716 DMS Titrino, Metrohm ${ }^{\circledR}$ ) that analyzed the samples with a potentiometric detector to determine the endpoint (Outdot et al. 1988).

In order to measure dark community respiration (DCR), samples in BOD bottles $(60 \mathrm{ml})$ were incubated in a water circulation tank, simulating in situ temperature $\left( \pm 1.5^{\circ} \mathrm{C}\right)$. DCR was determined from changes in DO during $24 \mathrm{~h}$ incubation. The variation coefficient of DCR measurement was $\sim 9 \pm 5 \%$, which was considered to be precise enough to measure respiration in coastal waters, although 5 replicates for respiration measurements have been recommended for oceanic waters where DO respiration is often $<3 \mu \mathrm{M} \mathrm{d}^{-1}$ (Robinson et al. 2002).

BR was measured at Stns 3, 5, 7 and 12 in July and November 2005 using the DCR method described above. A total of 4 bottles for the initial and 4 bottles for the dark incubation were filled with the $<1 \mu \mathrm{m}$ sizefractionated seawater, which was gravity-filtered (or with a low pressure $<15 \mathrm{~cm} \mathrm{Hg}$ ) onto $1 \mu \mathrm{m}$ polycarbonate membrane to avoid breakage of fragile cells. The membrane had to be replaced frequently to prevent it from being blocked by particles.

$\mathrm{BR}$ (or DIC produced by bacteria) is presented in carbon unit assuming the respiratory quotient (RQ) to be 1. Contribution of BR to gaseous $\mathrm{CO}_{2}$ efflux was calculated according to the increase in DIC due to $\mathrm{BR}$, and then the increase in $\mathrm{pCO}_{2}$, which was estimated by the equilibrium equation in the seawater (Mehrbach et al. 1973, Cai \& Wang 1998) assuming alkalinity did not change. $\mathrm{CO}_{2}$ flux was estimated using the stagnantfilm model (Wanninkhof 1992).

DIC and $\mathbf{p C O}_{2}$. Water samples $(50 \mathrm{ml})$ were preserved with saturated $\mathrm{HgCl}_{2}(20 \mu \mathrm{l})$ for DIC analysis and stored in a cool $\left(4^{\circ} \mathrm{C}\right)$ dark chamber. DIC was measured within $1 \mathrm{wk}$ by the subsequent quantification of $\mathrm{CO}_{2}$ with an infrared radiation (IR) detector (LI-COR 6252). This method has a precision of 0.1 to $0.2 \%$ (Cai \& Wang 1998). DIC was calibrated against certified reference material from A. Dickson, Scripps Institution of Oceanography, and a duplicate analysis was made every tenth sample (Dickson \& Goyet 1994). pH was measured with an Orion ROSS combination glass electrode that was calibrated against 3 National Bureau of Standards (NBS) standards (Dickson \& Goyet 1994). The precision of $\mathrm{pH}$ measurement was $\sim 0.01 . \mathrm{pCO}_{2}$ was calculated from measured $\mathrm{pH}$ values and DIC concentrations for estuarine and coastal waters (Cai \& Wang 1998). Direct and indirect $\mathrm{pCO}_{2}$ measurements have been previously determined to be in good agreement over a wide range of $\mathrm{pCO}_{2}$ and salinity values (Frankignoulle \& Borges 2001). In order to remove the temperature effect, $\mathrm{pCO}_{2}$ was normalized to an annual average temperature, using the equation by Takahashi et al. (2002). The $\mathrm{CO}_{2}$ flux across the air-sea interface is calculated by following the stagnant-film model (Wanninkhof 1992). The atmospheric $\mathrm{pCO}_{2}$, which varies by $\pm 20 \mu \mathrm{atm}$, was recorded to be $\sim 370 \mu \mathrm{atm}$ in the SCSwhich varies by $\pm 20 \mu \mathrm{atm}$ (Zhai et al. 2005).

Inorganic nutrients. Samples for nutrients were taken with a $60 \mathrm{ml}$ syringe and filtered through a precombusted Whatman GF/F filter mounted in a Swinnex filter holder and dispersed into Nalgene bottles (Thermo Fisher Scientific). All plastic-ware was precleaned with $10 \% \mathrm{HCl}$. The filtered water samples were placed in a cooler with dry ice and frozen until analysis. Nutrients (nitrate, phosphate and silicate) were measured with a Skalar SAN autoanalyzer following Joint Global Ocean Flux Study (JGOFS) protocols (Knap et al. 1994).

Statistical analyses. The significance of seasonal and spatial differences was assessed using an analysis of variance followed by a means comparison (2-tailed $t$-test) or 1-way ANOVA test, and a significance level of 0.05 was used to determine a significant statistical difference. The error bars represent a pooled sample $\mathrm{SD}$ of the means. In addition, the Pearson chi-squared test was used to obtain the correlation coefficient.

\section{RESULTS}

\section{Temperature and salinity}

In the dry season, the average surface temperature was $\sim 23$ to $25^{\circ} \mathrm{C}$ at all stations (Table 1), while surface salinities varied from $\sim 30$ to 34 , indicating the dominance of coastal seawater at all stations in Hong Kong waters. In the summer wet season, temperature was 

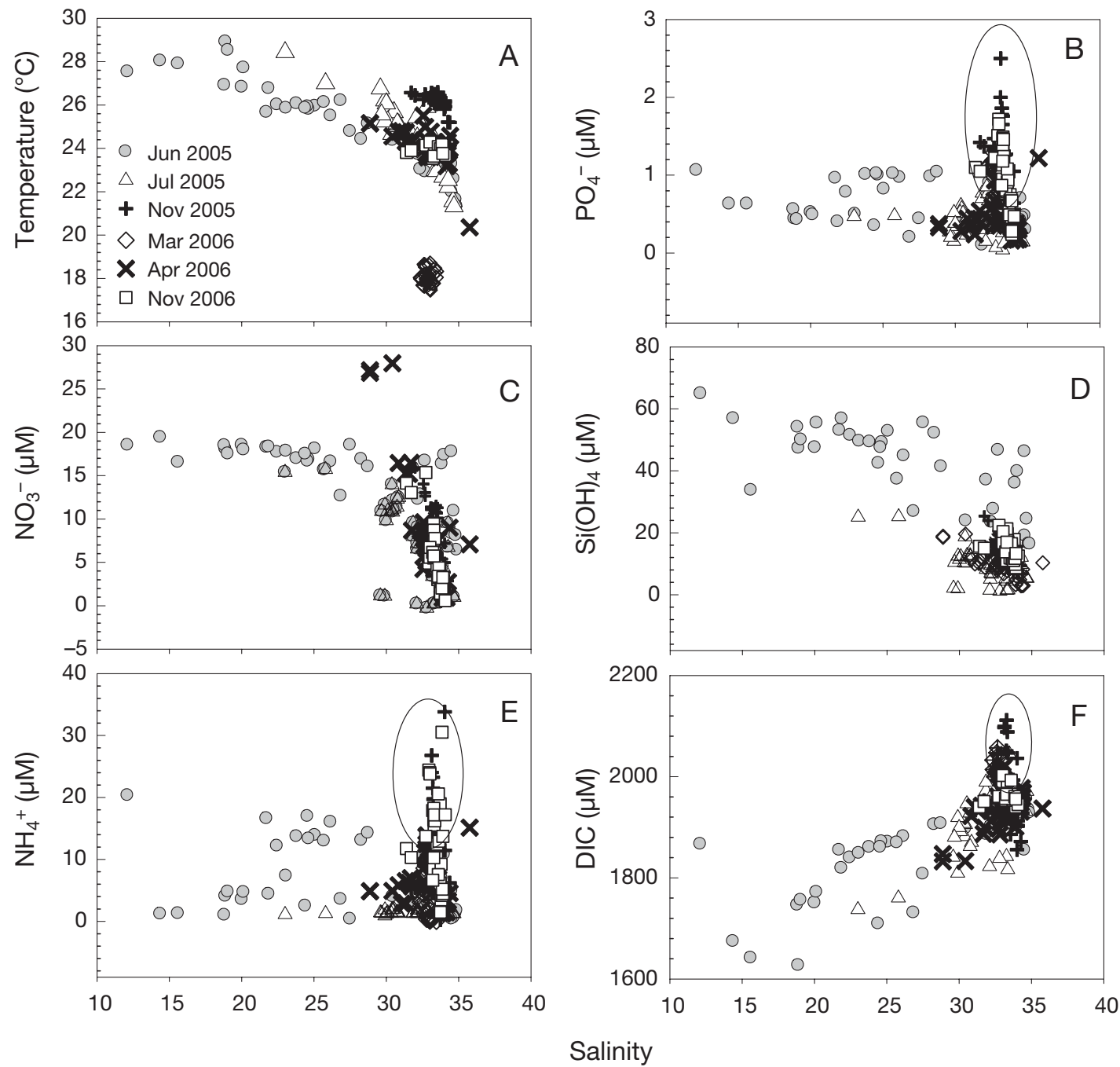

Fig. 2. Temperature, $\mathrm{DIC}, \mathrm{NO}_{3}{ }^{-}, \mathrm{Si}(\mathrm{OH})_{4}, \mathrm{NH}_{4}{ }^{+}$and $\mathrm{PO}_{4}{ }^{-}(\mu \mathrm{M})$ at the surface and bottom vs. salinity during June, July and November 2005 and March, April and November 2006. Circled data are mainly from Stns 3, 4 and 5 in the dry season (around the sewage discharge outfall)

$\sim 26^{\circ} \mathrm{C}$ (Table 1), and the temperature-salinity diagram showed that warm and low salinity waters were present in the wet season indicating a strong influence of the Pearl River discharge (Fig. 2A). Salinity in the PRE was the lowest $(\sim 14)$ and increased towards eastern waters ( 31) (Table 1). Compared to the dry season, salinities decreased by $\sim 30,20$ and $10 \%$ near the PRE, VH and eastern waters, respectively, in the wet season (Table 1).

\section{Nutrients}

The distribution of $\mathrm{NO}_{3}$ and $\mathrm{Si}(\mathrm{OH})_{4}$ followed the T-S relationship (Fig. 2C,D), with concentrations decreas- ing with salinity. In the wet season, $\mathrm{NO}_{3}$ and $\mathrm{Si}(\mathrm{OH})_{4}$ were high near the PRE due to the freshwater influence from the PRE, whereas they decreased markedly in eastern waters (Fig. 2C,D). The regression lines of $\mathrm{NO}_{3}$ and $\mathrm{Si}(\mathrm{OH})_{4}$ vs. salinity were often concave upward, which was most likely due to the external additions of $\mathrm{NO}_{3}$ and $\mathrm{Si}(\mathrm{OH})_{4}$ from sewage effluent.

In contrast to $\mathrm{NO}_{3}$ and $\mathrm{Si}(\mathrm{OH})_{4}, \mathrm{NH}_{4}$ and $\mathrm{PO}_{4}$ had different spatial distribution patterns and their concentrations were not significantly correlated with salinity $(\mathrm{r}<$ 0.1, $\mathrm{p}>0.05, \mathrm{n}=200$ ) (Fig. 2). $\mathrm{NH}_{4}$ and $\mathrm{PO}_{4}$ concentrations were relatively high at a salinity of 31 in $\mathrm{VH}$ near the sewage discharge site compared with other stations (see the data points within the circles in Fig. 2B,E). 

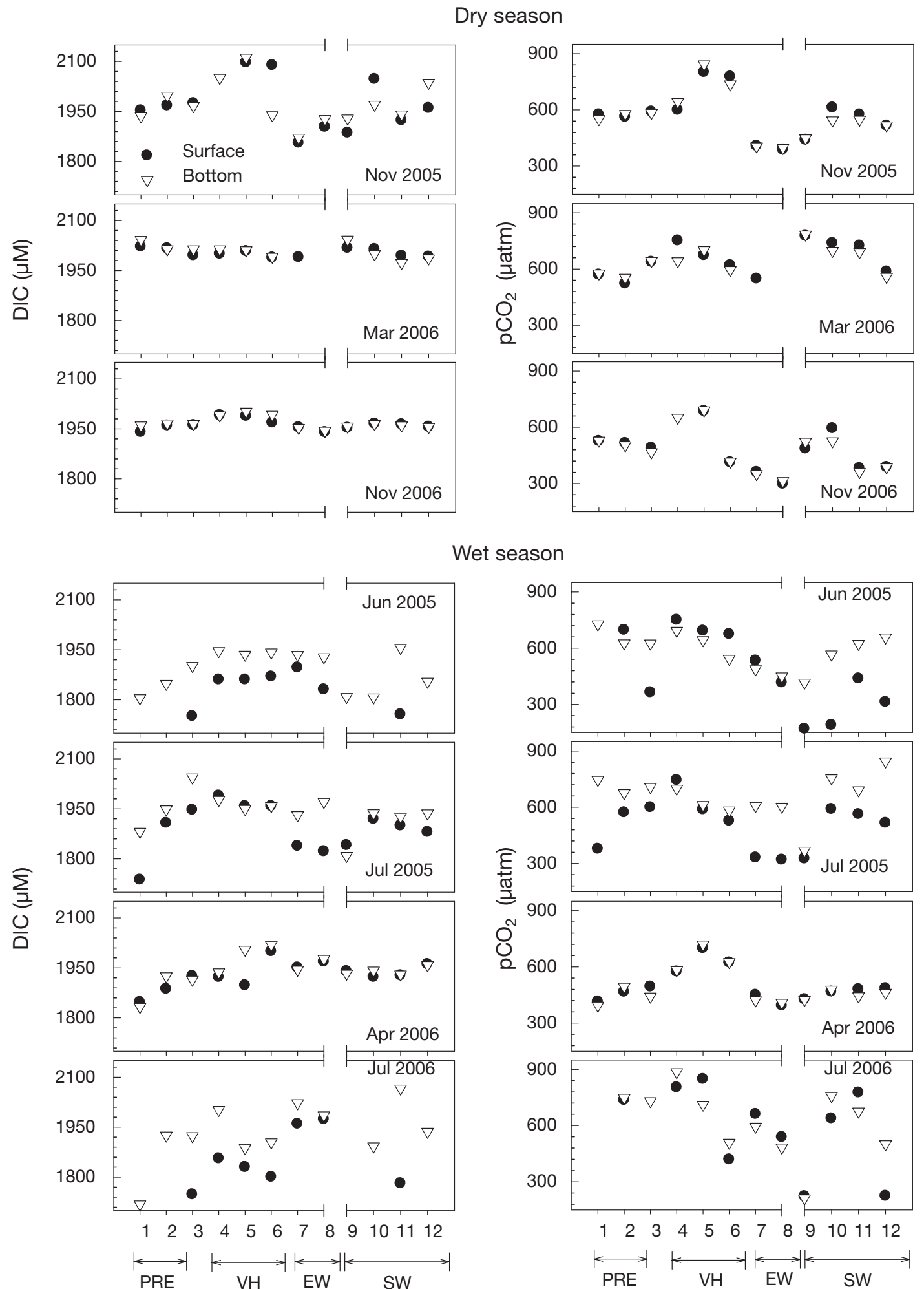

Stations

Fig. 3. Spatial distribution of dissolved inorganic carbon (DIC) and partial pressure of $\mathrm{CO}_{2}\left(\mathrm{pCO}_{2}\right)$ at 12 stations during June, July and November 2005 and March, April, July and November 2006. Stations were grouped into 4 sections: PRE (Pearl River estuary), VH (Victoria Harbor), EW (eastern waters) and SW (southern waters). Stn 3 is a transitional station between the PRE and VH. The separation in the $x$-axis between Stns 8 and 9 indicates the separation between the west to east transect and the north to south transect 


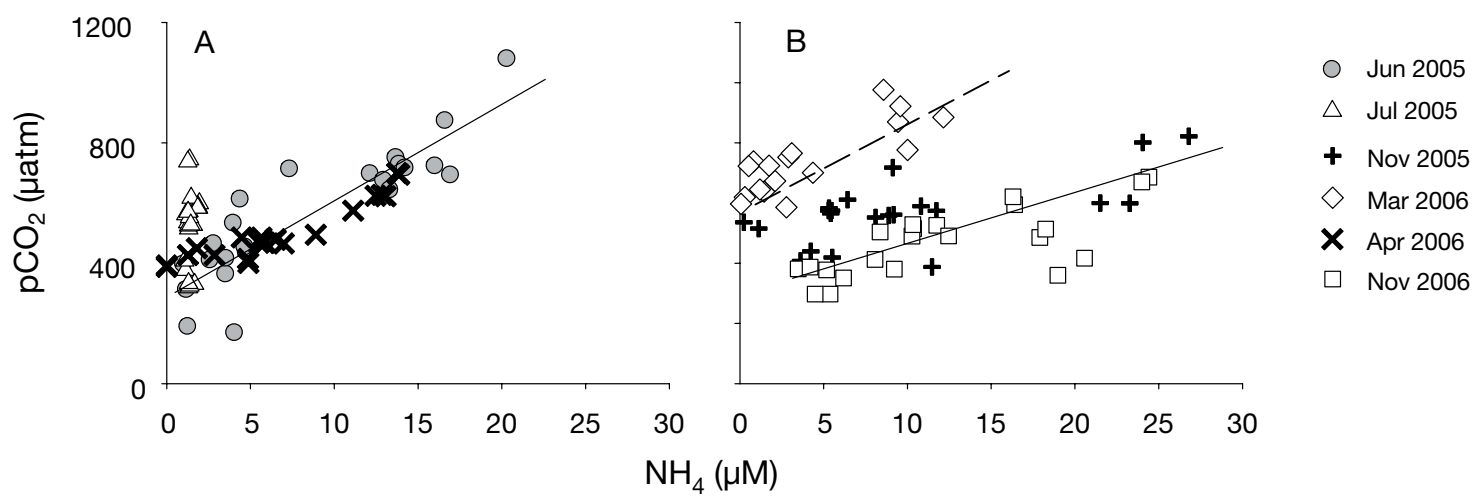

Fig. 4. Linear regression between surface ammonium $\left(\mathrm{NH}_{4}\right)$ and temperature-normalized $\mathrm{pCO}_{2}$ at all stations: (A) in the wet season $(r=0.8, p<0.05, n=60)$, and (B) the dry season (November 2005 and 2006: $r=0.8, p<0.05, n=40 ;$ March 2006: $r=0.8, p<$ $0.05, \mathrm{n}=20$ )

\section{DIC and $\mathrm{pCO}_{2}$}

Overall, DIC increased with salinity in the study area. In the dry season, spatial variations in DIC were not obvious at all 12 stations except in Nov 2005, when DIC increased from $\sim 1850 \mu \mathrm{M}$ in eastern waters to $2100 \mu \mathrm{M}$ in $\mathrm{VH}$ (Fig. 3). DIC concentrations were $\sim 1950 \mu \mathrm{M}$ and exhibited no significant difference between the surface and bottom (Fig. 3). In the wet season, DIC concentrations were usually $<1950 \mu \mathrm{M}$, being lower than the dry season. DIC was usually the lowest at Stn $1(<1900 \mu \mathrm{M})$ and increased towards Stn $8(\sim 1950 \mu \mathrm{M})$ (Fig. 3). In southern waters, DIC was very variable, ranging from $\sim 1500$ to $2000 \mu \mathrm{M}$ (Fig. 3).

In the wet season, $\mathrm{pCO}_{2}$ levels were consistently low in eastern waters ( 400 $\mu \mathrm{atm})$, but very variable near the PRE ( 300 to $1200 \mu \mathrm{atm})$ (Fig. 3). With a positive correlation with $\mathrm{NH}_{4}$ (Fig. 4), $\mathrm{pCO}_{2}$ was relatively high in $\mathrm{VH}(>600 \mu \mathrm{atm})$ where $\mathrm{NH}_{4}$ concentrations were also high, as compared to eastern waters $(\sim 300$ to

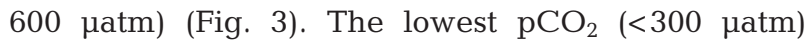
among all 12 stations occurred at Stn 9 in June 2005 and July 2006 (Fig. 3).

\section{DO and respiration}

In the dry season, DO concentrations were $\sim 210 \mu \mathrm{M}$ near the PRE and eastern waters and $\sim 170 \mu \mathrm{M}$ in $\mathrm{VH}$ (Table 1). In contrast, DO increased in eastern waters $(\sim 170 \mu \mathrm{M})$ but decreased near the PRE in the summer wet season (Table 1). The lowest DO often occurred in $\mathrm{VH}$ year round (Table 1).

DO saturation was usually $\sim 85 \%$ in the wet season and increased to $\sim 93 \%$ in the dry season near the PRE, while DO saturation was $\sim 80 \%$ near $\mathrm{VH}$ year round (Table 1), indicating that DO was generally undersaturated. In eastern waters, DO was usually super- saturated $(>100 \%)$ in the wet season, but slightly decreased in the dry season (Table 1 ).

DCR was $\sim 12$ to $25 \mu \mathrm{M} \mathrm{d}^{-1}$ and 3 to $13 \mu \mathrm{M} \mathrm{d}^{-1}$ in the wet and dry season, respectively (Table 2 ), and the bacterial fraction of DCR was $~ 50$ to $80 \%$ at Stns 7 and 12 in July and November 2005. Near VH, DCR and BR were $\sim 13$ and $11 \mu \mathrm{M} \mathrm{d}^{-1}$, respectively (Table 2), and hence the bacterial fraction of DCR was $>90 \%$ year round.

\section{Chl $a$, BA, BP and BGE}

In the dry season, surface chl a concentrations were constantly $<3 \mathrm{mg} \mathrm{m}^{-3}$ in eastern waters and $\mathrm{VH}$, but were occasionally high at $\sim 10 \mathrm{mg} \mathrm{m}^{-3}$ near the PRE (Fig. 5). In comparison with the dry season, surface chl a concentrations did not significantly increase near the PRE in the wet season. However, chl a concentrations in eastern waters and $\mathrm{VH}$ were generally high in the wet season $\left(\sim 3\right.$ to $\left.20 \mathrm{mg} \mathrm{m}^{-3}\right)$ and low in the dry season $\left(\sim 0.1\right.$ to $\left.4 \mathrm{mg} \mathrm{m}^{-3}\right)$. The highest surface chl $a$ occurred in the southern waters, which was as high as $30 \mathrm{mg} \mathrm{m}^{-3}$ (Fig. 5) and corresponded to the lowest $\mathrm{pCO}_{2}(<300 \mu \mathrm{atm})$ (Fig. 3).

Near the PRE, BP was negatively correlated with salinity (Fig. 6A). In eastern waters, BP was significantly correlated to chl a $(\mathrm{r}=0.2, \mathrm{p}<0.05, \mathrm{n}=20$ ) (Fig. $6 \mathrm{~B})$. The variations in BA were generally similar to BP (Fig. 5). BP was $\sim 1$ to $8 \mu \mathrm{M} \mathrm{C} \mathrm{d}^{-1}$ in $\mathrm{VH}$ (Stn 5) and $\sim 1$ to $3 \mu \mathrm{M} \mathrm{C} \mathrm{d}^{-1}$ in eastern waters year round.

In the wet season, bacterial growth efficiency (BGE) exhibited a pronounced gradient with a low value of 0.08 in eastern waters and high values of 0.2 and 0.3 in $\mathrm{VH}$ and southern waters, respectively (Table 2). In contrast to winter, there was no gradient, and BGE was $\sim 0.13$ in both the eastern waters and near the sewage discharge outfall in $\mathrm{VH}$, due to the invasion of coastal 
Table 2. Average $( \pm \mathrm{SD})$ surface dark community respiration (DCR), bacterial respiration (BR), bacterial fraction of DCR (BF), bacterial growth efficiency (BGE), and empirical BGE calculated with a conversion factor (CF) of $3 \mathrm{~kg} \mathrm{C} \mathrm{mol} \mathrm{leucine}{ }^{-1}$ (BGEe). Note:

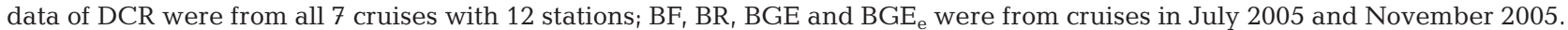
-: no measurement; $\mathrm{n}=$ number of replicates $\times$ number of cruises

\begin{tabular}{|c|c|c|c|c|c|c|c|c|c|c|}
\hline \multirow{2}{*}{ Stn } & \multicolumn{5}{|c|}{-Wet season } & \multicolumn{5}{|c|}{ - Dry season- } \\
\hline & $\begin{array}{c}\text { DCR } \\
\left(\mu \mathrm{M} \mathrm{C} \mathrm{d}^{-1}\right) \\
(\mathrm{n}=2 \times 7)\end{array}$ & $\begin{array}{c}\text { BR } \\
\left(\mu \mathrm{C} \mathrm{d}^{-1}\right) \\
(\mathrm{n}=4 \times 2)\end{array}$ & $\begin{array}{c}\mathrm{BF} \\
(\mathrm{n}=4 \times 2)\end{array}$ & $\begin{array}{c}\text { BGE } \\
(\mathrm{n}=3 \times 2)\end{array}$ & $\begin{array}{c}\mathrm{BGE}_{\mathrm{e}} \\
(\mathrm{n}=3 \times 2)\end{array}$ & $\begin{array}{c}\text { DCR } \\
\left(\mu \mathrm{M} \mathrm{C} \mathrm{d}^{-1}\right) \\
(\mathrm{n}=2 \times 7)\end{array}$ & $\begin{array}{c}\text { BR } \\
\left(\mu \mathrm{C} \mathrm{d}^{-1}\right) \\
(\mathrm{n}=4 \times 2)\end{array}$ & $\begin{array}{c}\mathrm{BF} \\
(\mathrm{n}=4 \times 2)\end{array}$ & $\begin{array}{c}\text { BGE } \\
(\mathrm{n}=3 \times 2)\end{array}$ & $\begin{array}{c}\mathrm{BGE}_{\mathrm{e}} \\
(\mathrm{n}=3 \times 2)\end{array}$ \\
\hline 1 & $19 \pm 9$ & - & & - & - & $9 \pm 6$ & - & & - & - \\
\hline 2 & $16 \pm 6$ & - & & - & - & $9 \pm 6$ & - & & - & - \\
\hline 3 & $12 \pm 2$ & $11 \pm 2$ & 0.9 & $0.20 \pm 0.02$ & $0.13 \pm 0.02$ & $9 \pm 6$ & - & & - & - \\
\hline 4 & $13 \pm 3$ & - & & - & - & $13 \pm 3$ & - & & - & - \\
\hline 5 & $13 \pm 3$ & $11 \pm 4$ & 0.9 & $0.20 \pm 0.06$ & $0.13 \pm 0.1$ & $12 \pm 6$ & $11 \pm 3$ & 0.9 & $0.13 \pm 0.02$ & $0.09 \pm 0.01$ \\
\hline 6 & $19 \pm 9$ & - & & - & - & $6 \pm 0$ & - & & - & - \\
\hline 7 & $19 \pm 6$ & $13 \pm 3$ & 0.7 & $0.08 \pm 0.01$ & $0.03 \pm 0.01$ & $3 \pm 3$ & $3 \pm 1$ & 0.9 & $0.13 \pm 0.03$ & $0.09 \pm 0.01$ \\
\hline 8 & $19 \pm 9$ & - & & - & - & $3 \pm 2$ & - & & - & - \\
\hline 9 & $21 \pm 9$ & - & & - & - & $6 \pm 3$ & - & & - & - \\
\hline 10 & $25 \pm 9$ & - & & - & - & $6 \pm 3$ & - & & - & - \\
\hline 11 & $16 \pm 6$ & - & & - & - & $9 \pm 4$ & - & & - & - \\
\hline 12 & $18 \pm 6$ & $4 \pm 1$ & 0.5 & $0.3 \pm 0.02$ & $0.2 \pm 0.02$ & $6 \pm 3$ & - & & - & - \\
\hline
\end{tabular}

waters during the period of the downwelling when the NE monsoon winds occurred.

\section{DISCUSSION}

\section{Undersaturated DO and supersaturated $\mathrm{CO}_{2}$}

The variability in DO is a measure of water quality, but it is also indicative of ecosystem metabolism. For example, the percentage oxygen saturation (or apparent oxygen utilization) can be used to infer respiration by planktonic organisms in the ocean by assuming that surface oxygen concentration in a water body of low biological activity is close to saturation with the overlying atmosphere (Ito et al. 2004). The average percentage oxygen saturation in $\mathrm{VH}$ near the sewage discharge site steadily declined from $83.4 \%$ in 1973 to $61.6 \%$ in 1983 due to an increase in nutrient loading from sewage effluent (Yung et al. 1999). However, starting in November 2001, about $70 \%$ of the sewage in HK has been receiving chemically enhanced primary treatment (CEPT), in which about $7 \mathrm{t}$ per day of suspended solids are removed. Our results showed that despite the removal of some suspended solids, the average percentage oxygen saturation at the surface in $\mathrm{VH}$ (Stn 5) was $\sim 78 \pm 8 \%$ in the wet season and $\sim 85 \pm$ $4 \%$ in the dry season during 2005 and 2006 (Table 1), which was significantly higher than that in 1983 (65 \pm $5 \%)(t=4.5$, df $=25, \mathrm{p}<0.05)$.

Supersaturated $\mathrm{CO}_{2}$ can be an indication of high respiration and, hence, heterotrophy. The coastal waters of Hong Kong exhibited supersaturated $\mathrm{CO}_{2}$ concentrations $\left(\mathrm{pCO}_{2}>370 \mu \mathrm{atm}\right)$ at all 12 stations during
2005 and 2006. The exception was that $\mathrm{pCO}_{2}$ at the surface was low (<200 $\mu \mathrm{atm})$ (Fig. 3) when surface chl a concentrations were $>20 \mathrm{mg} \mathrm{m}^{-3}$ at Stns 9 and 10 in June 2005 when an algal bloom occurred. The predominance of $\mathrm{CO}_{2}$ supersaturation suggested that $\mathrm{CO}_{2}$ release due to respiration exceeded photosynthetic carbon uptake in Hong Kong waters. Previous studies also suggested that estuaries and adjacent waters which receive large external inputs of organic matter may respire more carbon than they produce internally through phytoplankton production (Raymond et al. 2000).

Undersaturated DO and supersaturated $\mathrm{CO}_{2}$ were also found in some European and U.S. estuaries such as Scheldt and Satilla, with $\mathrm{pCO}_{2}>5000 \mu$ atm and DO $<100 \mu \mathrm{M}$ indicating high respiration due to loadings of organic matter from pollution (Frankignoulle et al. 1998, Gazeau et al. 2004, 2005), or from intertidal marshes (Cai \& Wang 1998). In Hong Kong coastal waters, surface $\mathrm{pCO}_{2}$ was usually $<1000$ atm, which was lower than upstream in the PRE

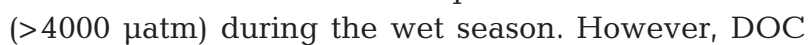
$(\sim 170$ to $180 \mu \mathrm{M})$ in $\mathrm{VH}$ (data not shown) was often higher than upstream in the PRE (100 to $170 \mu \mathrm{M})$ in the wet season (Zhang et al. 1999). The high DOC and relatively low $\mathrm{pCO}_{2}$ in $\mathrm{VH}$, as compared to upstream in the PRE, indicated that there might not be sufficient time for the bacteria to respire and consume DOC. Strong mixing appears to play an important role in regulating $\mathrm{DO}$ and $\mathrm{pCO}_{2}$ in Hong Kong coastal waters. It would take at least $15 \mathrm{~d}$ to respire all $\mathrm{DO}$, if DCR is $\sim 13 \mu \mathrm{M} \mathrm{d}^{-1}$ in the wet season, but the average residence time is only $\sim 1.5$ to $2.5 \mathrm{~d}$ in the wet season in VH (Kuang \& Lee 2004). 


\section{Influence of the PRE}

The eastern waters exhibited the least variations in salinity, DO and DIC between the wet and dry seasons, due to less influence from freshwater discharge. However, near the PRE in the western region, the freshwater discharge from the PRE caused a considerable decrease in DIC and an increase in DOC concentrations in the wet

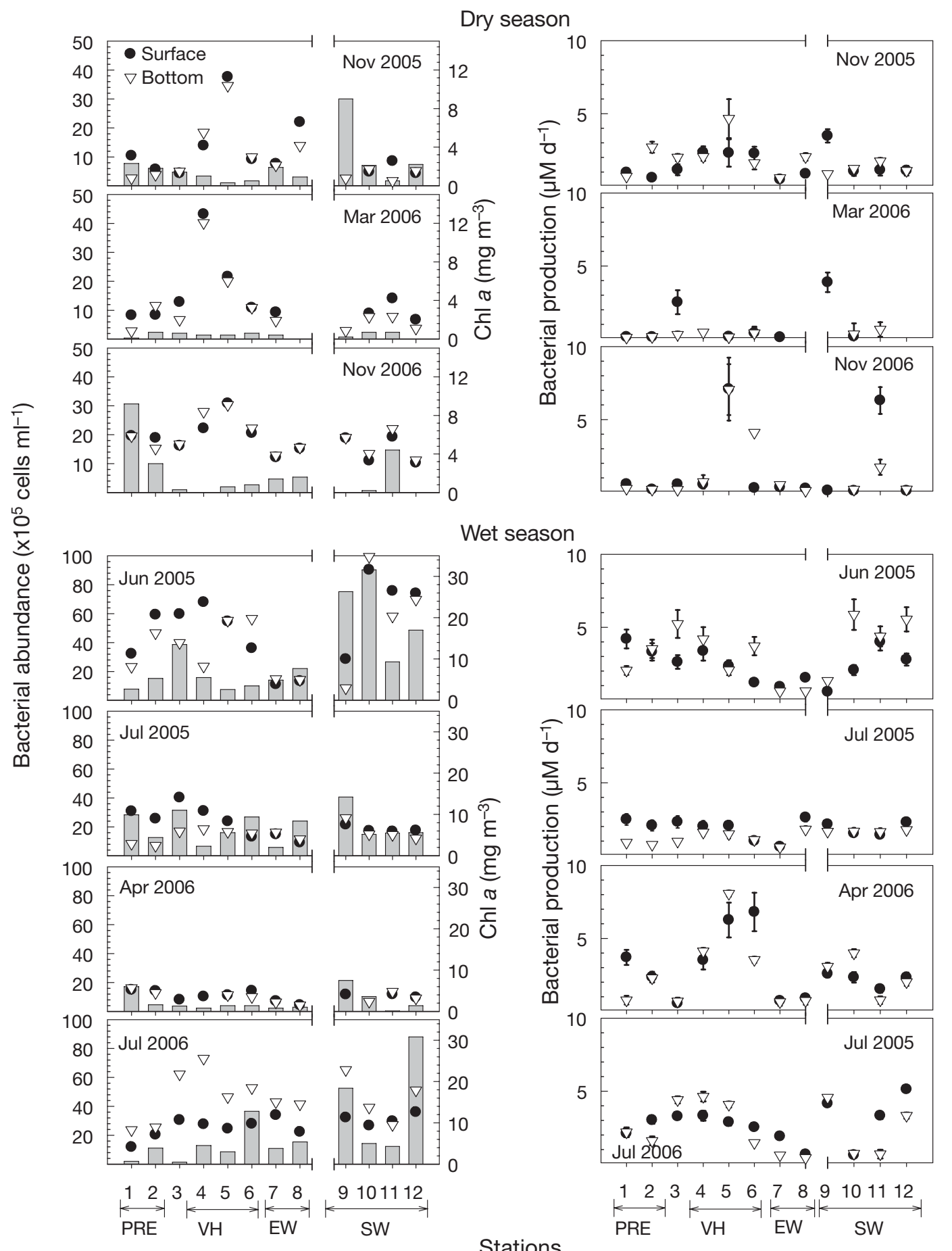

Fig. 5. Bacterial abundance (BA) and bacterial production (BP) along 12 stations during June, July and November 2005 and March, April, July and November 2006 (for abbreviations and explanation see Fig. 3). Stn 3 is a transitional station between the PRE and VH. Surface chl a concentrations are also shown as vertical gray bars. Error bars are \pm 1 SD (for BP only). Note the different scale for the dry and wet seasons 


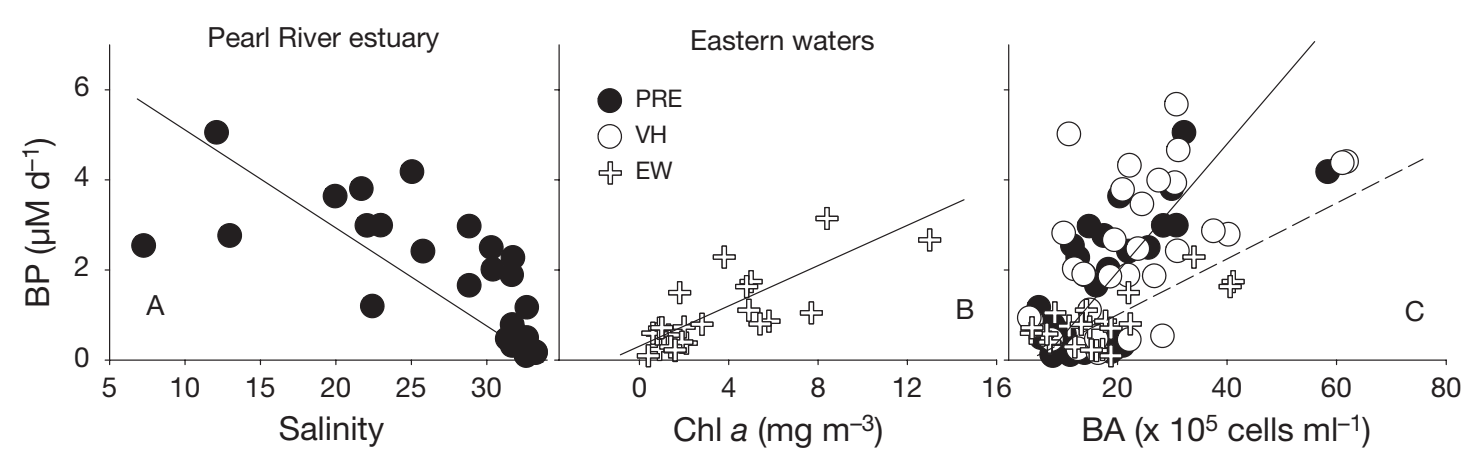

Fig. 6. The relationship of bacterial production (BP) with (A) salinity in the PRE (Pearl River estuary; Stns 1 and 2 ) ( $\mathrm{r}=-0.7$, $\mathrm{p}<$ 0.05, $\mathrm{n}=20$ ), (B) chl $\mathrm{a}$ in eastern waters (EW) (Stns 7 and 8) $(\mathrm{r}=0.8, \mathrm{p}<0.05, \mathrm{n}=20)$, and (C) bacterial abundance (BA) in the PRE $(\mathrm{r}=0.5, \mathrm{p}<0.05, \mathrm{n}=20), \mathrm{VH}$ (Victoria Harbor; $\mathrm{r}=0.5, \mathrm{p}<0.05, \mathrm{n}=20)$ and EW $(\mathrm{r}=0.8, \mathrm{p}<0.05, \mathrm{n}=19)$

season. $\mathrm{NO}_{3}$ and $\mathrm{Si}(\mathrm{OH})_{4}$ concentrations were also strongly influenced by the freshwater outflow from the PRE, as indicated by significant correlations with salinity (Fig. 2C,D).

In addition to nutrients, the freshwater from the PRE also appeared to regulate the variations in BP near the PRE, as BP near the PRE was significantly correlated with salinity (Fig. 6A). In contrast, BP in eastern waters was significantly correlated with chl a (Fig. 6B) but not salinity, indicating phytoplankton was an important regulating factor of $\mathrm{BP}$ in eastern waters. Due to the dominant influence of high sewage effluent throughout the year in $\mathrm{VH}, \mathrm{BP}$ exhibited no correlation either with salinity or chl $a$. In addition, the slope of the regression between $\mathrm{BP}$ and $\mathrm{BA}$ was higher near the PRE and VH than eastern waters (Fig. 6C), indicating higher BP:BA ratios or higher production per cell near the PRE and $\mathrm{VH}$, likely due to high inputs of nutrients and organic matter.

An important question concerning estuarine ecosystem functionality is whether it is autotrophic or heterotrophic. Recent observations have shown that estuarine systems may release a significant amount of $\mathrm{CO}_{2}$ into the atmosphere in addition to the export of inorganic/organic matter to marine systems. For example, Frankignoulle et al. (1998) estimated that the amount of $\mathrm{CO}_{2}$ outgassed from European estuaries is equivalent to 5 to $10 \%$ of the present anthropogenic $\mathrm{CO}_{2}$ emission from Western Europe, and hence estuaries are significant sources of $\mathrm{CO}_{2}$ to the atmosphere that is higher than the $\mathrm{CO}_{2}$ emission to the atmosphere from rivers, streams and lakes (Borges et al. 2006). In the Changjiang (Yangtze) River estuary, $\mathrm{pCO}_{2}$ of 800 to 2000 Hatm was observed in mixing zones (Zhang et al. 1999). In the inner $\mathrm{PRE}, \mathrm{pCO}_{2}$ was as high as $\sim 4000$ patm (Zhai et al. 2005). All of these studies demonstrated that anthropogenic organic matter in an estuary can enhance the respiration rate and hence $\mathrm{CO}_{2}$ production.

\section{Impacts of sewage effluent}

As discussed in the last section, higher bottom DO during our sampling periods than in 1983 in VH (Yung et al. 1999) indicates that the water quality has improved. Previous studies documented that sewage effluent was a major source of $\mathrm{NH}_{4}$ in $\mathrm{VH}$, since $\mathrm{NH}_{4}$ was higher than on either side of the harbor (Yin \& Harrison 2007). Similarly, there was lower DO and higher $\mathrm{pCO}_{2}$ and $\mathrm{BP}$ near the new sewage discharge site than eastern waters and the PRE in most of the sampling months. Hence, the significant correlation between $\mathrm{NH}_{4}$ and $\mathrm{pCO}_{2}$ indicated that $\mathrm{pCO}_{2}$ was strongly influenced by sewage effluent during 2005 and 2006 (Fig. 4), as the organic inputs from sewage effluent supported the production and release of high amounts of $\mathrm{CO}_{2}$. In addition, sewage effluent might also increase bacterial growth rate, and this suggestion was supported by the test for homogeneity of slopes, which indicated that the slope of BP vs. BA in VH was significantly different from eastern waters $\left(F_{1,29}=6.9\right.$, $\mathrm{p}<0.05$ ) (Fig. 6).

The range of BP in Hong Kong waters was similar to the Mississippi River, where hypoxia typically occurs during the summer (Rabalais et al. 1994, Rabouille et al. 2008). However, not all estuaries receiving high nutrient loading exhibit high heterotrophy that could lead to hypoxia/anoxia, due to short residence times, or rapid flushing of the bottom layer, as occurred in the James River, a tributary of Chesapeake Bay (Kuo \& Neilson 1987). High flushing also reduces hypoxic events in Hong Kong waters.

\section{Significance of BR and BGE}

There may be some methodological concerns about the measurement of $\mathrm{BR}$, which are mainly attributed to the filtration process which results in less predators, 
broken cells, autotrophic picophytoplankton $(<1 \mu \mathrm{m})$ passing through the filter and attached bacteria retained on the filter (Pomeroy et al. 1994, Preen \& Kirchman 2004). In the present study, larger and attached bacteria were responsible for only a small portion of respiration, since we checked to see if larger and attached bacteria had been removed by $1 \mu \mathrm{m}$ filtration and found that there was no significant difference in BA between in filtered and nonfiltered waters $(t=1.5, \mathrm{df}=5, \mathrm{p}>0.05)$. In addition, autotrophic picophytoplankton, which emit red light under green excitation and are distinct from heterotrophic bacteria, were seldom observed in the filtrate under epifluorescence microscopy.

$\mathrm{BR}$ is crucial for the estimation of BGE, which is a key factor in understanding bacterial influence on carbon flow in aquatic ecosystems. However, there are only a few studies on BGE in which BR and BP has been measured simultaneously. In those studies, there were always some uncertainties in BGE measurements due to the CFs for BP (Alonso-Sáez et al. 2007). In the present study, CFs $(\sim 4.5 \pm 3$ and $\sim 3.5 \pm 1.5 \mathrm{~kg} \mathrm{C} \mathrm{mol}$ leucine $^{-1}$ ) were slightly higher than the CF of $\sim 3 \mathrm{~kg} \mathrm{C}$ mol leucine ${ }^{-1}$ estimated by Pedrós-Alió et al. (1999) in coastal waters, and the theoretical CF of $\sim 3 \mathrm{~kg} \mathrm{C} \mathrm{mol}$ leucine ${ }^{-1}$ by Simon \& Azam (1989). In the present study, BGE was 30 to $50 \%$ lower when a different CF was used (Table 2).

BGE varied from $\sim 0.08$ to 0.30 in Hong Kong waters and even lower when applying an empirical CF ( 3 kg C mol leucine ${ }^{-1}$ ), which was in the low range in many other studies (e.g. Biddanda et al. 1994, Reinthaler \& Herndl 2005, Alonso-Sáez et al. 2007). The relatively low BGE indicated that most of carbon passing through the bacterial community was largely respired rather than converted into bacterial biomass. Previous studies showed that BGE might be affected by substrate availability and composition in marine systems (Pomeroy \& Wiebe 2001). In addition, it has been suggested that BGE is high where carbon limitation and no inorganic nutrient limitation are found (AlonsoSáez et al. 2007). Nutrient limitation might be one of explanations for the relatively low BGE in Hong Kong waters, since phosphorus addition could enhance BGE in Hong Kong waters (X. Yuan et al. unpubl. data). In addition, the variability in BGE in Hong Kong waters was mainly due to the variations in BP, as BR varied from 1- to 3-fold over a seasonal cycle (Table 2), while BP varied up to $>10$-fold (Fig. 5), in agreement with a previous study (Reinthaler \& Herndl 2005).

The bacterial fraction of the DCR was higher at Stn $5(\sim 92 \pm 6 \%)$ than Stns 7 and $12(80 \pm 15 \%)$ (Fig. 7A), suggesting that larger plankton was less important near the sewage discharge outfall in terms of respiration. The bacterial fraction of the DCR ( 70 to $90 \%$ ) was higher than previous estimations (12 to $59 \%$ ) (Robinson \& Williams 2005) but similar to that in the coastal Mediterranean (89\%) (VázquezDomínguez et al. 2007) and in the southern Bay of Biscay $(70 \%)$ (González et al. 2003). BR was a dominant contributor to oxygen consumption in Hong Kong waters, which supports the notion that heterotrophy in Hong Kong waters was mainly due to BR. Such high BR would certainly consume a high amount of organic carbon discharged from the PRE and sewage effluent as well as autochthonous labile DOC (e.g. phytoplankton exudation).

Apart from oxygen consumption, the bacterial contribution to the air-sea efflux of gaseous $\mathrm{CO}_{2}$ was also considerable (Fig. 7C). BR accounted for a gaseous $\mathrm{CO}_{2}$ efflux of $\sim 3$ to $10 \mathrm{mmol} \mathrm{C} \mathrm{m}^{-2} \mathrm{~d}^{-1}$ (Fig. 7C,D), which was only $~ 50 \%$ (varying from 16 to $130 \%$ ) of the total $\mathrm{CO}_{2}$ efflux, suggesting that there should be another source for $\mathrm{CO}_{2}$ release, since the utilization of $\mathrm{CO}_{2}$ by phytoplankton must offset some portion of the $\mathrm{CO}_{2}$ efflux. The contribution of BR to the $\mathrm{CO}_{2}$ efflux was $\sim 20$ to $100 \%$ of the $\mathrm{CO}_{2}$ efflux in the York River estuary based on a different estimation method (Ray-
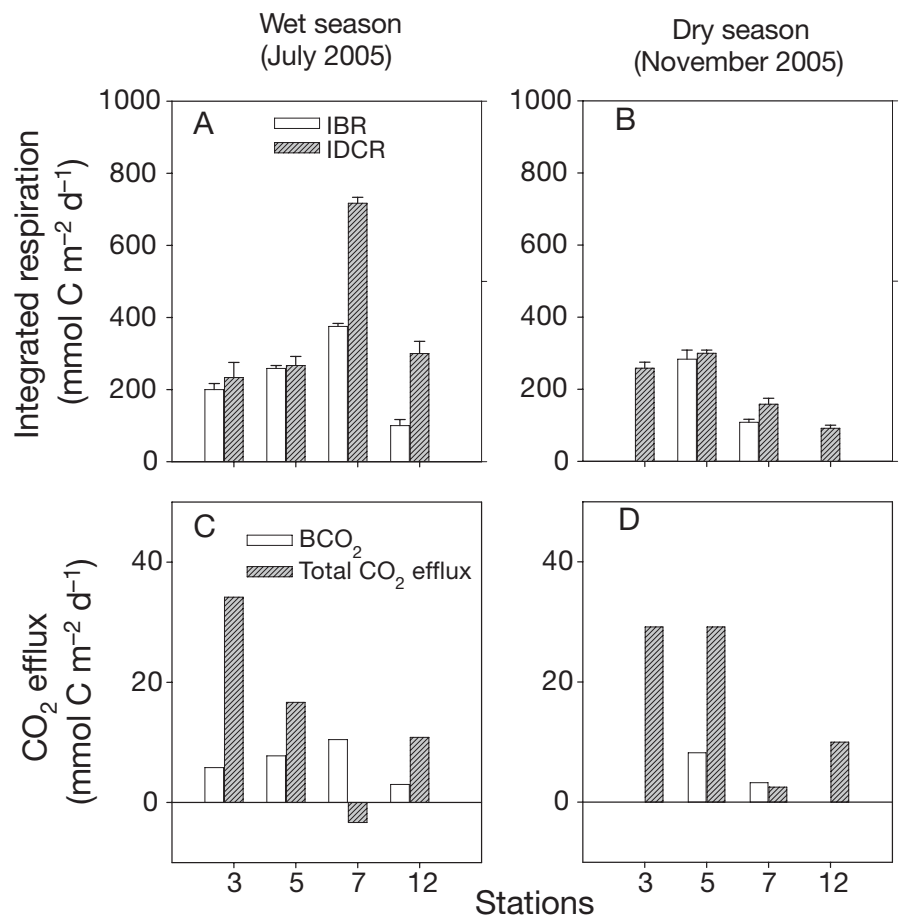

Fig. 7. Vertically integrated bacterial respiration (IBR) $(n=4)$ (see integrated depths in Table 1); integrated dark community respiration (IDCR; $\mathrm{n}=2$ ) at Stns 3, 5, 7 and 12 in (A) July 2005 and (B) November 2005. Contributions of $\mathrm{BR}$ to $\mathrm{CO}_{2}$ efflux $\left(\mathrm{BCO}_{2}\right)$ and total $\mathrm{CO}_{2}$ efflux in (C) July 2005 and (D) November 2005. Bacterial respiration was not measured at Stns 3 and 12 in November 2005. Error bars are $\pm 1 \mathrm{SD}$ 
mond \& Bauer 2000). As Raymond \& Bauer (2000) suggested, the large discrepancy between contributions of $\mathrm{BR}$ to $\mathrm{CO}_{2}$ efflux and total $\mathrm{CO}_{2}$ efflux must arise from (1) water-column remineralization of organic carbon in the $>1 \mu \mathrm{m}$ size fraction, and (2) sediment respiration. In addition, $\mathrm{CO}_{2}$ efflux might be increased by rivers inputs, since rivers are generally highly supersaturated in dissolved $\mathrm{CO}_{2}$ (Frankignoulle et al. 1998, Raymond et al. 2000). Coastal upwelling may also affect the carbon balance and $\mathrm{pCO}_{2}$ by bringing higher DIC from greater depths into nearshore waters (Huthnance 1995, Wollast 1998). The influence of such physical processes on $\mathrm{CO}_{2}$ flux might also be important in Hong Kong waters when upwelling occurs due to the southwest monsoon in summer and downwelling induced by the northeast monsoon in winter.

Our results demonstrated that Hong Kong waters were net heterotrophic, with a net efflux of $\mathrm{CO}_{2}$ from surface waters, which suggested that DCR exceeded gross primary production. Kemp et al. (1997) and Hopkinson \& Vallino (1995) concluded that the metabolic balance between respiration and primary production in estuaries and the nearby coastal zone depended on the ratio of inputs of dissolved inorganic nutrient to labile organic carbon. With increased eutrophication, net ecosystem metabolism could shift and become more heterotrophic or autotrophic depending on the ratio (Ducklow \& McCallister 2004). In Hong Kong waters in the summer, there might be an excess of labile organic carbon relative to dissolved inorganic nutrients, especially P concentrations in the summer, as a P addition increased BGE when inorganic nutrients were relatively deficient (X. Yuan et al. unpubl. data).

Acknowledgements. This research was part of an Area of Excellence (AoE/P-04/04) project sponsored by the University Grants Council of Hong Kong, RGC HKUST (6296/03M and 6505/06M) and the CAS/SAFEA International Partnership Program for Creative Research Teams, as well as NSFC\#40676074. We thank Rivkin Richard for helpful comments on an earlier draft of this manuscript and the staff in Environmental Central Facility and Coastal Marine Laboratory of HKUST for their helpful service.

\section{LITERATURE CITED}

Abril G, Etcheber H, Delille B, Frankignoulle M, Borges AV (2003) Carbonate dissolution in the turbid and eutrophic Loire estuary. Mar Ecol Prog Ser 259:129-138

Alonso-Sáez L, Gasol JM, Arístegui J, Vilas JC, Vaqué D, Duarte CM, Agustí S (2007) Large scale variability in surface bacterial carbon demand and growth efficiency in the subtropical North East Atlantic Ocean. Limnol Oceanogr 52:533-546

Benson BB, Krause D (1984) The concentration and isotopic fractionation of oxygen dissolved in freshwater and seawater in equilibrium with the atmosphere. Limnol Oceanogr 29:620-632
Biddanda B, Opsahl S, Benner R (1994) Plankton respiration and carbon flux through bacterioplankton on the Louisiana shelf. Limnol Oceanogr 39:1259-1275

Biddanda B, Ogdahl M, Cotner J (2001) Dominance of bacterial metabolism in oligotrophic relative to eutrophic waters. Limnol Oceanogr 46:730-739

Borges AV, Schiettecatte LS, Abril G, Delille B, Gazeau F (2006) Carbon dioxide in European coastal waters. Estuar Coast Shelf Sci 70:375-387

Cai WJ, Wang Y (1998) The chemistry, fluxes and sources of carbon dioxide in the estuarine waters of the Satila and Altamaha Rivers, Georgia. Limnol Oceanogr 43:657-668

Cai WJ, Dai MH, Wang YC, Zhai WD and others (2004) The biogeochemistry of inorganic carbon and nutrients in the Pearl River estuary and the adjacent Northern South China Sea. Cont Shelf Res 24:1301-1319

Cai WJ, Dai M, Wang Y (2006) Air-sea exchange of carbon dioxide in ocean margins: a province-based synthesis. Geophys Res Lett 33, L12603, doi:10.1029/2006 GL026219

> Chen CC, Shiah FK, Gong GH, Chiang KP (2003) Planktonic community respiration in the East China Sea: importance of microbial consumption of organic carbon. Deep-Sea Res 50:1311-1325

Chin-Leo G, Benner R (1992) Enhanced bacterioplankton production and respiration at intermediate salinities in the Mississippi River plume. Mar Ecol Prog Ser 87:87-103

Choi DH, Yang SR, Hong GH, Chung CS, Kim SH, Park JS, Cho BC (2005) Different interrelationships among phytoplankton, bacterial and environmental variables in dumping and reference areas in the East Sea. Aquat Microb Ecol 41:171-180

> Dai MH, Guo XH, Zhai WD, Yuan LY and others (2006) Oxygen depletion in the upper reach of the Pearl River estuary during a winter drought. Mar Chem 102:159-169

Del Giorgio PA, Cole JJ, Cimbleris A (1997) Respiration rates in bacteria exceed plankton production in unproductive aquatic systems. Nature 385:148-151

Dickson AG, Goyet C (eds) (1994) Handbook of methods for the analysis of the various parameters of the carbon dioxide system in seawater, Version 2.0. Carbon Dioxide Information Analysis Center, Oak Ridge National Laboratory, Oak Ridge, TN, p 1-18

Ducklow HW, McCallister SL (2004) The biogeochemistry of carbon dioxide in the coastal oceans. In: Robinson AR, Brink K, Rothschild BJ (eds) The sea, Vol 13, Chap 9. The Global Coastal Ocean. Harvard University Press, Cambridge, MA, p 269-315

> Frankignoulle M, Borges AV (2001) Direct and indirect $\mathrm{pCO}_{2}$ measurements in a wide range of $\mathrm{pCO}_{2}$ and salinity values. Aquat Geochem 7:267-273

Frankignoulle M, Bourge I, Wollast R (1998) Carbon dioxide emission from European estuaries. Science 282:434-436

Gazeau F, Gentili B, Frankignoulle M, Smith SV, Gattuso JP (2004) The European coastal zone: characterization and first assessment of ecosystem metabolism. Estuar Coast Shelf Sci 60:673-694

> Gazeau F, Gattuso JP, Middelburg JJ, Brion N, Schiettecatte LS, Frankignoulle M, Borges AV (2005) Planktonic and whole system metabolism in a nutrient-rich estuary (the Scheldt Estuary). Estuaries 28:868-883

> González N, Anadón R, Viesca L (2003) Carbon flux through the microbial community in a temperate sea during summer: role of bacterial metabolism. Aquat Microb Ecol 33: $117-126$

Hopkinson CS, Vallino JJ (1995) The relationship between man's activities in watersheds and rivers and patterns of estuarine community metabolism. Estuaries 18:598-621 
Huthnance JM (1995) Circulation, exchange, and water masses at the ocean margin: the role of physical processes at the shelf edge. Prog Oceanogr 35:353-431

Ito T, Follows MJ, Boyle EA (2004) Is AOU a good measure of respiration in the oceans? Geophys Res Lett 31, L17305, doi:10.1029/2004GL020900

Kemp WM, Smith EM, Marvin-DiPasquale M, Boynton WR (1997) Organic carbon balance and net ecosystem metabolism in Chesapeake Bay. Mar Ecol Prog Ser 150:229-248

Kirchman DL, Suzuki Y, Garside C, Ducklow HW (1991) High turnover rates of dissolved organic carbon during a spring phytoplankton bloom. Nature 352:612-614

Knap A, Michaels A, Close A, Ducklow H, Dickson A (eds) (1994) Protocols for the Joint Global Ocean Flux Study (JGOFS) core measurement. Scientific Committee on Ocean Research. Manual and Guides 29. UNESCO, Paris, p 119-122

Kuang CP, Lee JHW (2004) Impact of reclamation and HATS Stage I on Victoria Harbour, Hong Kong. In: Lee JH, Lam KM (eds) Proc Fourth Int Symp Environmental Hydraulics. Balkema, Rotterdam, p 1163-1168

> Kuo AY, Neilson BJ (1987) Hypoxia and salinity in Virginia estuaries. Estuaries 10:277-283

Li DJ, Zhang J, Huang DJ, Wu Y, Liang J (2002) Oxygen depletion off the Changjiang (Yangtze River) Estuary. Sci China Ser D 45:1137-1146

Lohrenz SE, Fahnenstiel GL, Redalje DG, Lang GA, Dagg MJ, Whitledge TE, Dortch Q (1999) Nutrients, irradiance, and mixing as factors regulating primary production in coastal waters impacted by the Mississippi River plume. Cont Shelf Res 19:1113-1141

Mehrbach C, Cuberson CH, Hawley JE, Pytkowicz RM (1973) Measurements of the apparent dissociation constants of carbonic acid in seawater at atmospheric pressure. Limnol Oceanogr 18:897-907

NRC (National Research Council) (2000) Clean coastal waters: understanding and reducing the effects of nutrient pollution. National Academy Press, Washington, DC, p 11-36

Outdot CR, Gerard R, Morin P, Gningue I (1988) Precise shipboard determination of dissolved oxygen (Winkler procedure) for productivity studies with a commercial system. Limnol Oceanogr 33:146-150

Pedrós-Alió C, Calderón-Paz J, Guixa-Boixereu N, Estrada M, Gasol JM (1999) Bacterioplankton and phytoplankton biomass and production during summer stratification in the northwestern Mediterranean Sea. Deep-Sea Res I 46: 985-1019

Pomeroy LR, Wiebe WJ (2001) Temperature and substrates as interactive limiting factors for marine heterotrophic bacteria. Aquat Microb Ecol 23:187-204

Pomeroy LR, Sheldon JE, Sheldon WM (1994) Changes in bacterial numbers and leucine assimilation during estimations of microbial respiratory rates in seawater by the precision Winkler method. Appl Environ Microbiol 60: 328-332

Porter KG, Feig YS (1980) The use of DAPI for identifying and counting aquatic microflora. Limnol Oceanogr 25:943-948

> Preen K, Kirchman DL (2004) Microbial respiration and production in the Delaware estuary. Aquat Microb Ecol 37: 109-119

Rabalais NN, Wiseman WJ, Turner RE (1994) Comparison of continuous records of near-bottom dissolved oxygen from the hypoxia zone along the Louisiana coast. Estuaries 17: 850-861

Rabouille C, Conley DJ, Dai MH, Cai WJ and others (2008) Comparison of hypoxia among four river-dominated ocean margins: the Changjiang (Yangtze), Mississippi, Pearl, and Rhône rivers. Cont Shelf Res 28:1527-1537
Raymond PA, Bauer JE (2000) Bacterial consumption of DOC during transport through a temperate estuary. Aquat Microb Ecol 22:1-12

Raymond PA, Caraco NF, Cole JJ (1997) Carbon dioxide concentration and atmospheric flux in the Hudson River. Estuaries 20:381-390

Raymond PA, Bauer JE, Cole JJ (2000) Atmospheric $\mathrm{CO}_{2}$ efflux, dissolved inorganic carbon production, and net heterotrophy in the York River estuary. Limnol Oceanogr 45:1707-1717

> Reinthaler T, Herndl GJ (2005) Seasonal dynamics of bacterial growth efficiencies in relation to phytoplankton in the southern North Sea. Aquat Microb Ecol 39:7-16

Robinson C, Williams PJ leB (2005) Respiration and its measurement in surface marine waters. In: del Giorgio PA, Williams PJ leB (eds) Respiration in aquatic ecosystems. Oxford University Press, Oxford, p 147-180

Robinson C, Serret P, Tilstone G, Teira E, Zubkov MV, Rees AP, Woodward EMS (2002a) Plankton respiration in the Eastern Atlantic Ocean. Deep-Sea Res I 49:787-813

Robinson C, Widdicombe CE, Zubkov MV, Tarran GA, Miller AEJ, Rees AP (2002b) Plankton community respiration during a coccolithophore bloom. Deep-Sea Res II 49: 2929-2950

> Simon M, Azam F (1989) Protein content and protein synthesis rates of planktonic marine bacteria. Mar Ecol Prog Ser 51:201-213

Smith SV, Hollibaugh JT (1993) Coastal metabolism and the oceanic organic carbon balance. Rev Geophys 31:75-89

- Takahashi T, Sutherland SC, Sweeney C, Poisson A and others (2002) Global sea-air $\mathrm{CO}_{2}$ flux based on climatological surface ocean $\mathrm{pCO}_{2}$, and seasonal biological and temperature effects. Deep-Sea Res II 49:1601-1622

> Vázquez-Domínguez E, Vaque D, Gasol JM (2007) Ocean warming enhances respiration and carbon demand of coastal microbial plankton. Glob Change Biol 13:1327-1334

- Wanninkhof R (1992) Relationship between wind speed and gas exchange over the ocean. J Geophys Res 97:7373-7382

Wollast R (1998) Evaluation and comparison of the global carbon cycle in the coastal zone and in the open ocean. In: Brink KH, Robinson AR (eds) The sea, Vol 10. The global coastal ocean. Wiley, New York, p 213-252

Yin K, Harrison PJ (2007) Influence of the Pearl River estuary and vertical mixing in Victoria Harbor on water quality in relation to eutrophication impacts in Hong Kong waters. Mar Pollut Bull 54:646-656

Yin K, Qian PY, Chen JC, Hsieh DPH, Harrison PJ (2000) Dynamics of nutrients and phytoplankton biomass in the Pearl River estuary and adjacent waters of Hong Kong during summer: preliminary evidence for phosphorus and silicon limitation. Mar Ecol Prog Ser 194:295-305

> Yin K, Lin ZF, Ke ZY (2004) Temporal and spatial distribution of dissolved oxygen in the Pearl River estuary and adjacent coastal waters. Cont Shelf Res 24:1935-1948

Yung YK, Yau K, Wong CK, Chan KK, Yeung I, Kueh CSW, Broom MJ (1999) Some observations on the changes of physicochemical and biological factors in Victoria Harbour and vicinity, Hong Kong, 1988-1996. Mar Pollut Bull 39:315-325

> Zhai WD, Dai MH, Cai WJ, Wang YC, Hong HS (2005) The partial pressure of carbon dioxide and air-sea fluxes in the northern South China Sea in spring, summer and autumn. Mar Chem 93:21-32

Zhang LJ, Wang BY, Zhang J (1999) $\mathrm{pCO}_{2}$ in the surface water of the East China Sea in winter and summer. J Ocean Univ Qingdao 5(suppl.):149-153

Zhao H (1990) Evolution of the Pearl River Estuary. Ocean Press, Beijing, p 1-110 